\title{
Does Loss of Nerve Growth Factor Receptors Precede Loss of Cholinergic Neurons in Alzheimer's Disease? An Autoradiographic Study in the Human Striatum and Basal Forebrain
}

\author{
Ornella Strada, ${ }^{1}$ Etienne C. Hirsch, ${ }^{1}$ France Javoy-Agid, ${ }^{1}$ Stéphane Lehéricy, ${ }^{1}$ Merle Ruberg, ${ }^{1}$ Jean-Jacques \\ Hauw, ${ }^{2}$ and Yves Agid' \\ 'Laboratoire de Médecine Expérimentale, INSERM U289, and 2Laboratoire de Neuropathologie R. Escourolle, Hôpital de \\ la Salpêtrière, 75013 Paris, France
}

\begin{abstract}
The mechanism by which cholinergic neurons degenerate in Alzheimer's disease is not known. Some of these neurons depend, however, on trophic support from NGF via a membrane receptor. We have analyzed the state of these receptors by autoradiography, with ${ }^{125}$ |-NGF as the ligand, in the caudate nucleus, putamen, ventral striatum, nucleus basalis of Meynert, and nucleus tegmenti pedunculopontinus of six patients with Alzheimer's disease and five controls, matched for age and postmortem delay. The binding characteristics were similar in the striatum (including caudate nucleus, putamen, and ventral striatum) and basal forebrain of control subjects and patients with Alzheimer's disease $\left(K_{d}=2.5-4\right.$ $\times 10^{-11} \mathrm{M}$ ). In control brains, high levels of ${ }^{125}$-NGF binding were observed in the basal forebrain and striatum (0.32-0.49 fmol/mg tissue equivalent), but no specific binding was detected in the nucleus tegmenti pedunculopontinus. NGF binding sites were distributed heterogeneously in the striatum with patches of low density, corresponding to AChEpoor striosomes, surrounded by a matrix in which receptor density was significantly greater. In Alzheimer's disease, the density of NGF receptors was markedly decreased in the caudate nucleus, putamen, ventral striatum, and nucleus basalis of Meynert. In contrast, AChE staining decreased less in the nucleus basalis of Meynert in all Alzheimer's disease patients, and in the ventral striatum of those most severely affected.

These results indicate that if NGF receptors are located on cholinergic neurons, receptor loss and the consequent decrease in trophic support may precede cell degeneration in Alzheimer's disease. The relationship between the loss of these receptors and the pathogenesis of the disease remains to be determined.
\end{abstract}

The most constantly reported neurochemical alteration in Alzheimer's disease (AD) is the loss of ChAT activity in the cerebral

\footnotetext{
Received Feb. 28, 1992; revised Junc 11, 1992; acceptcd Junc 29, 1992.

We thank Drs. C. Duyckaerts, F. Piette, M. Laurent, H. Beck, J. Belmin, J. Rozen, and D. Deslandes for providing postmortem material; and Drs. P. Michel and A. Kastner (INSERM U289), and Drs. A. Brandi and D. Bression (INSERM $\mathrm{U} 223$ ) for their help with the receptor binding studies. O.S. was supported by a fellowship from INSERM (Paris, France) and the Associazione Amici Del Centro Dino Ferrari (Milan, Italy). This work was supported by INSERM and a grant from the Ministère de la Recherche et de la Technologie (89.C.0708)

Correspondence should be addressed to Ornella Strada, Laboratoire de Médecine Expérimentale, INSERM U289, Hôpital de la Salpêtrière, 47 Bd de l'Hôpital, 75013 Paris, France.

Copyright (C) 1992 Society for Neuroscience $0270-6474 / 92 / 124766-09 \$ 05.00 / 0$
}

cortex (Rossor et al., 1982). Cholinergic innervation of the cortex originates in the nucleus basalis of Meynert, where neuronal loss is observed in AD patients (Hefti and Mash, 1989; Kordower et al., 1989; Mufson et al., 1989a,b; Allen et al., 1990; Ernfors et al., 1990). A marked loss of cholinergic interneurons has also been observed in the ventral striatum (Lehéricy et al., 1989), whereas other cholinergic nuclei are not affected (Woolf et al., 1989a; Brandel et al., 1991). Why these neurons degenerate is not known.

It has been hypothesized that degenerative changes that affect cholinergic neurons in the nucleus basalis may be caused by lack of trophic support by NGF (Thocnen ct al., 1987; Whittcmore and Seiger, 1987). Immunohistochemical studies have demonstrated the presence of NGF receptors on cholinergic neurons in the basal forebrain of animals and humans, but have failed to detect the protein in the striatum or the mesencephalon (Hefti and Mash, 1989; Kordower et al., 1989; Mufson et al., $1989 \mathrm{~b}$; Woolf et al., 1989b). High-affinity receptors were detected in both the basal forebrain and the striatum of the rat by autoradiography (Richardson et al., 1986; Raivich and Kreutzberg, 1987), but not in the mesencephalon (Richardson et al., 1986).

The observation that NGF receptors are present on cholinergic neurons in the basal forebrain that degenerate in $\mathrm{AD}$, and are absent in the mesencephalon where cholinergic neurons are spared, suggests that the vulnerability of the basal forebrain neurons may be related to their NGF dependency. The present study was, therefore, undertaken to examine the state of NGF receptors in cholinergic nuclei of brains from normal subjects and patients with $\mathrm{AD}$. The receptors were visualized by immunohistochemistry with a monoclonal antibody and by autoradiography with ${ }^{125} \mathrm{I}-\mathrm{NGF} 2.5 \mathrm{~S}$ (referred to hereafter as ${ }^{125}$ I-NGF).

\section{Patients and Methods}

Patients. Five control subjects with no known history of psychiatric or neurological disorders and six paticnts with AD were studied (Table 1). All patients had been institutionalized in a geriatric department. AD was diagnosed clinically, in conformity with the criteria of the National Institute of Neurological and Communicative Disorders and StrokesAlzheimer's Disease and Related Disorders Association (McKhann, 1984). The diagnosis was confirmed after autopsy by counting silverimpregnated senile plaques (Bodian, 1936; Lamy et al., 1989) in the temporal and frontal cortex, as described previously (Ransmayr et al., 1989). Age at death, brain weights, and time elapsed between death and tissue conservation were similar in controls and AD patients (Table 1).

Tissue preparation. After autopsy, brains were quickly removed, 


\begin{tabular}{|c|c|c|c|c|c|c|c|c|}
\hline $\begin{array}{l}\text { Brain } \\
\text { no. }\end{array}$ & $\begin{array}{l}\text { Age } \\
\text { (years) }\end{array}$ & Sex & $\begin{array}{l}\text { Clinical } \\
\text { diagnosis }\end{array}$ & Associated pathology & Therapy & $\begin{array}{l}\text { Post- } \\
\text { mortem } \\
\text { delay (hr) }\end{array}$ & $\begin{array}{l}\text { Brain } \\
\text { weight } \\
\text { (gm) }\end{array}$ & $\begin{array}{l}\mathrm{SP} / \mathrm{mm}^{2} \\
\text { in the } \\
\text { cortex }\end{array}$ \\
\hline 1 & 92 & $\mathbf{F}$ & Control & Cardiac arrhythmia & Haloperidol & 27 & 1270 & 2 \\
\hline 2 & 92 & $\mathbf{F}$ & Control & $\begin{array}{l}\text { Rectosigmoid } \\
\text { carcinoma }\end{array}$ & & 19 & 1000 & 4 \\
\hline 3 & 68 & $\mathrm{~F}$ & Control & $\begin{array}{l}\text { Metabolic acidosis, } \\
\text { cardiac failure }\end{array}$ & & 10 & - & 5 \\
\hline 4 & 82 & $\mathbf{M}$ & Control & - & & 3 & 1030 & 7 \\
\hline 5 & 92 & $\mathbf{F}$ & Control & Myocardial infarction & & 19 & 1100 & 2 \\
\hline 6 & 95 & $\mathbf{F}$ & Alzheimer & Sigmoid carcinoma & Benzodiazepines & 3.5 & 1100 & 24 \\
\hline 7 & 83 & $\mathrm{~F}$ & Alzheimer & $\begin{array}{l}\text { Breast cancer, } \\
\text { cardiac arrhythmia }\end{array}$ & & 4.5 & 1180 & 108 \\
\hline 8 & 90 & $\mathbf{F}$ & Alzheimer & Mitralic failure & & 4 & 1220 & 8 \\
\hline 9 & 74 & $\mathrm{~F}$ & Alzheimer & Liver metastases & $\begin{array}{l}\text { Benzodiazepines } \\
\text { Haloperidol } \\
\text { Thioridazine }\end{array}$ & 11 & 1120 & 11 \\
\hline 10 & 85 & $\mathrm{~F}$ & Alzheimer & $\begin{array}{l}\text { Cardiovascular } \\
\text { collapsus }\end{array}$ & & 19 & - & 23 \\
\hline 11 & 82 & $\mathrm{~F}$ & Alzheimer & Renal failure & & 6 & 1040 & 41 \\
\hline
\end{tabular}

SP, senile plaques (Bodian silver impregnation).

hemisected, and cut rostrocaudally into $1.5-2-\mathrm{cm}$-thick slabs. The striatum (two blocks) and the mesencephalon (one block) were dissected from the slabs and either fixed (see below) for immunohistochemistry, or frozen immediately in powdered dry ice and stored at $-80^{\circ} \mathrm{C}$, until sectioned for autoradiography and acetylcholinesterase staining. Tissue was fixed, as previously described (Graybiel et al., 1987), for $3 \mathrm{~d}$ in $4 \%$ (w/v) paraformaldehyde, $15 \%$ picric acid (saturated solution), frozen in powdered dry ice, cut in serial free-floating sections $(40 \mu \mathrm{m})$ on a freezing microtome, and stored at $4^{\circ} \mathrm{C}$ in $0.25 \mathrm{M}$ Tris- $\mathrm{HCl}(\mathrm{pH} \mathrm{7.4)}$, with $0.9 \%$ $\mathrm{NaCl}$ and $0.1 \% \mathrm{NaN}_{3}$ until used. Frozen tissue was cut in serial sections $(20 \mu \mathrm{m})$ in a cryostat at $-12^{\circ} \mathrm{C}$ in the frontal plane for the striatum and transversely for the brainstem. Sections were thaw mounted on gelatinchrome alum-coated slides (double subbed), and stored desiccated for at least 3 weeks at $-80^{\circ} \mathrm{C}$ before processing. Sections at equivalent anatomical levels were used for immunohistochemistry and autoradiography.

Standards ("striatum standards") containing different dilutions of AChE were obtained using striatum homogenates of one additional control patient. In brief, one block of tissue containing the striatum was frozen in dry ice, and the gray and white matter were separated. Onehalf and one-fifth volume of phosphate buffer $(0.1 \mathrm{M}), 0.9 \% \mathrm{NaCl}$ containing peptidase inhibitors $(20 \mu \mathrm{g} / \mathrm{ml}$ pepstatin, $40 \mu \mathrm{g} / \mathrm{ml}$ leupeptin, and $1 \mathrm{~mm}$ phenylmethylsulfonyl fluoride) were added, respectively, to the white and gray matter. They were then homogenized for $5 \mathrm{~min}$ in an UltratuRRax and $7 \mathrm{~min}$ in a sonicator. Eight dilutions of striatum gray matter homogenates were prepared using the white matter homogenate as dilutor. Fach dilution $(250 \mu \mathrm{l} \mathrm{each})$ was then injected into a block of frozen Tissue-Tek (Miles) in which eight wells had been bored. The block of Tissue-Tek containing the homogenate deposits was then cut in $20 \mu \mathrm{m}$ serial sections on a cryostat at $-10^{\circ} \mathrm{C}$. Sections were collected on gelatin-coated glass slides and stored at $-80^{\circ} \mathrm{C}$ before $\mathrm{AChE}$ histochemistry was performed.

Immunohistochemistry. Sections from a control subject (female, age 74 years; postmortem delay, $7 \mathrm{hr}$ ) and a patient with Alzheimer's disease (male, age 80 years; postmortem delay, $9 \mathrm{hr}$ ) were incubated with a mouse monoclonal antibody against the human low-affinity NGF receptor (Amersham, clone ME20-4) diluted 1:10. Immunoreactivity was revealed using the double bridge peroxidase-antiperoxidase method (Sternberger, 1979; Graybiel et al., 1987), with $0.05 \%$ diaminobenzidine and $0.01 \mathrm{M}$ imidazole.

${ }^{125} I-N G F 2.5 S$ autoradiography. In all subjects, receptor binding studies were performed at two comparable levels in the striatum: at the level of the nucleus basalis of Meynert, and at the level where the ventral striatum was the most developed. These levels were defined according to anatomical landmarks such as the anterior commissure, and the appearance of the nucleus accumbens. In one control brain (no. 4), the entire striatum was serially sectioned rostrocaudally, and analyzed every $800 \mu \mathrm{m}$ (16 levels). In two control subjects (no. 1 and 3) and four AD patients (no. 7-10), sections through the mesencephalic nucleus tegmenti pedunculopontinus (cholinergic group Ch5; Mesulam et al., 1983) were analyzed.

Autoradiography was performed with ${ }^{125} \mathrm{I}-\mathrm{NGF} 2.5 \mathrm{~S}$, the $\beta$-chain of the NGF molecule responsible for its biological activity (Levi-Montalcini and Angeletti, 1968), on triplicate sections, as described by Richardson et al. (1986). Briefly, after a 10 min preincubation in PBS $(0.1$ $M$ Na-phosphate $\mathrm{pH} 7.4,0.9 \% \mathrm{NaCl}$ ), slide-mounted sections were incubated for $90 \mathrm{~min}$, at room temperature, in a humid atmosphere, in $600 \mu \mathrm{l}$ of PBS containing ${ }^{125} \mathrm{I}-\mathrm{NGF} 2.5 \mathrm{~S}$ (Amersham; $1500 \mathrm{Ci} / \mathrm{mmol}$ ), $0.5 \mathrm{~mm}$ magnesium chloride (Prolabo, Paris, France), $1 \mathrm{mg} / \mathrm{ml}$ cytochrome C (Sigma Chemical Co.), $4 \mathrm{mg} / \mathrm{ml}$ leupeptin (Boehringer Mannheim), and $0.5 \mathrm{~mm}$ phenylmethylsulfonyl fluoride (Sigma Chemical Co.). After three 2 min rinses with ice-cold PBS, the slides were quickly dipped in cold distilled water, dried under a current of cool air, and exposed to tritium-sensitive film (Amersham, Hyperfilm ${ }^{3} \mathrm{H}$ ) for $11 \mathrm{~d}$ at room temperature. For quantification, ${ }^{125}$ I microscale standards (1.13-629 $\mathrm{nCi} / \mathrm{mg}$ tissue equivalent; Amersham) were included with each film. Films were developed with Kodak AL4 developer $\left(1.5 \mathrm{~min}, 18^{\circ} \mathrm{C}\right)$, rinsed, and fixed with Kodak LX24 fixative ( $5 \mathrm{~min}$ ).

The density of NGF receptors in control subjects and $\mathrm{AD}$ patients was determined with $4 \times 10^{-11} \mathrm{M}$ 125I-NGF. Nonspecific binding was determined in the presence of $4 \times 10^{-8} \mathrm{M}$ unlabeled NGF. These concentrations were determined by saturation and displacement experiments as follows.

Saturation experiments were performed with 11 concentrations of ${ }^{125}$ I-NGF $\left(0.5-10 \times 10^{-11} \mathrm{M}\right)$, on serial sections from the striatum of a control brain, at the level of the nucleus basalis of Meynert, and of an AD patient, where the dorsal and ventral striatum were well developed. Labeled sections were washed in cold PBS followed by distilled water, lifted from slides on GF/B filters (Whatman), and counted. The $K_{d}$ and $B_{\max }$ were determined from the saturation curves.

Displacement of ${ }^{125}$ I-NGF at a concentration of $4 \times 10^{-11} \mathrm{M}\left(=K_{d}\right)$ by 11 concentrations of unlabeled NGF $\left(5 \times 10^{-11} \mathrm{M}\right.$ to $\left.1 \times 10^{-5} \mathrm{M}\right)$ was performed on the striatum of a control brain. Sections were analyzed from autoradiograms (see below), and the $K_{i}$ calculated from the equation $K_{i}=\mathrm{IC}_{50}\left(1+L / K_{j}\right)$.

Acetylcholinesterase histochemistry. Tissue sections adjacent to those used for the binding assays as well as those containing the striatum standards were stained for acetylcholinesterase (AChE) activity, ac- 

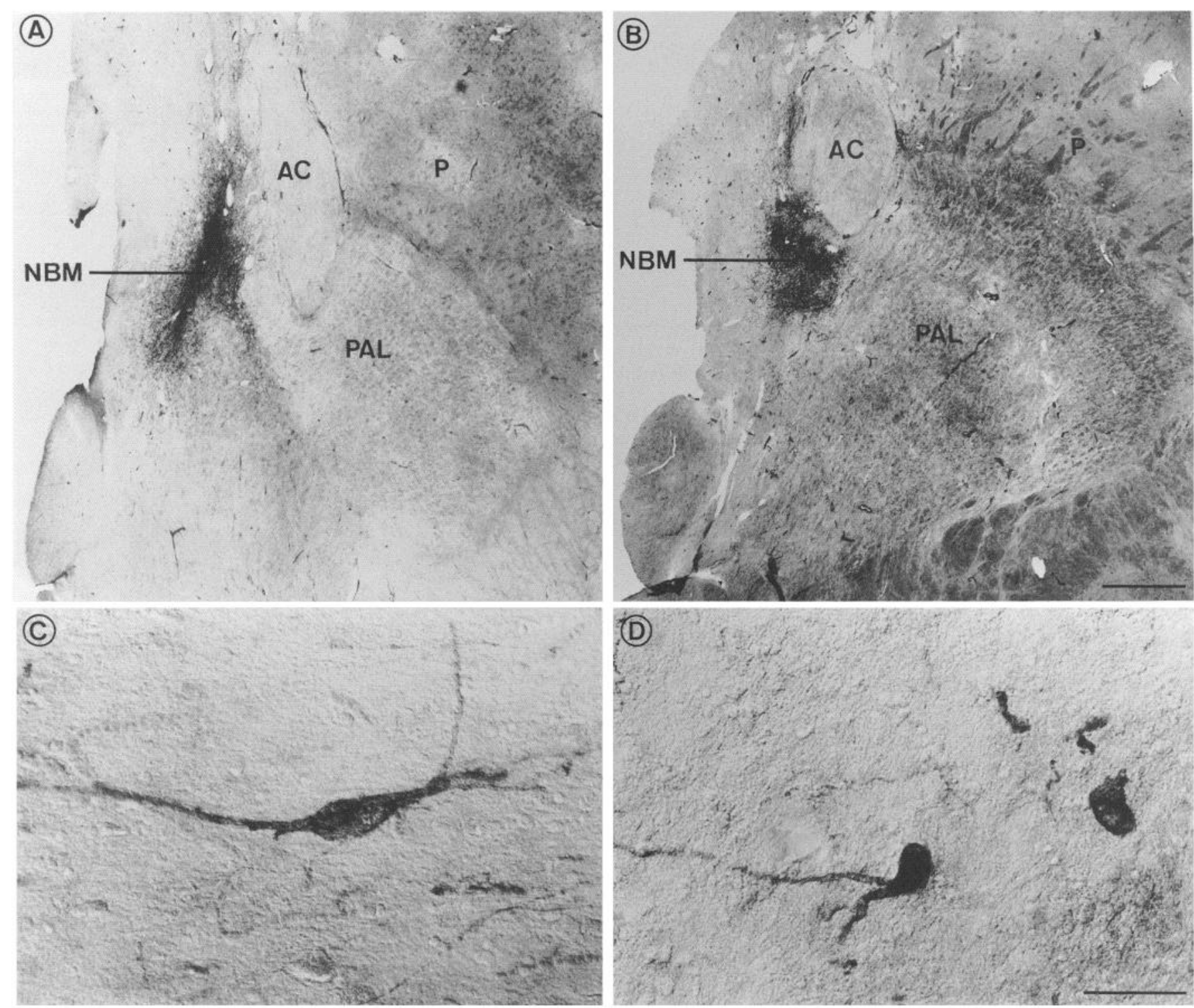

Figure 1. Frontal sections of the human basal forebrain stained with a monoclonal antibody against the human NGF receptor. $A$, Control subject. $B$, Patient with $\mathrm{AD}$. $C$, Immunoreactive neuron in the control brain. $D$, Surviving neurons in the AD brain. $A C$, anterior commissure; $N B M$, nucleus basalis of Meynert; $P$, putamen; $P A L$, pallidum. $C$ and $D$ were taken with Nomarski interference-contrast. Scale bars: $A$ and $B, 2$ mm; $C$ and $D, 50 \mu \mathrm{m}$.

cording to a slightly modified version of the Geneser-Jensen Blackstad method, as described elsewhere (Graybiel and Ragsdale, 1978). Striatum standards were incubated for $1,1.5,2,2.5$, or $5 \mathrm{hr}$ with the AChE solution and striatal tissue for $1.5 \mathrm{hr}$.

Regions of analysis. For each staining, measurements were performed in the caudate nucleus, putamen, ventral striatum, nucleus basalis of Meynert, and nucleus tegmenti pedunculopontinus. The boundaries of these regions were determined on AChE-stained sections. The same boundaries were taken to define the regions on the autoradiograms for receptor binding analysis. The limit between the dorsal striatum (including the putamen and caudate nucleus) and ventral striatum (including the nucleus accumbens) was arbitrarily defined by a line perpendicular to the midline of the internal capsule at its lower edge (Lehéricy et al., 1989). The dorsal striatum was also divided into an upper and lower portion, for quantitative analysis. Within the striatum, measurements were performed in striosomes, defined as AChE-poor zones, and in the surrounding matrix (Graybiel and Ragsdale, 1978; Hirsch et al., 1989).

Image analysis. The intensity of AChE staining in homogenates and tissue sections of striatum and the density of ${ }^{125} \mathrm{I}-\mathrm{NGF}$ binding sites on the autoradiograms were determined with an image analyzer (HISTORAG, BIOCOM, Les Ulis, France).

The intensity of AChE staining was determined by measuring the optical density in the different structures on the sections and on standards from striatal tissue. The intensity of specific AChE staining was determined after substracting the background staining, taken as the optical density in the internal capsule (a region that does not contain AChE activity).

Quantification of ${ }^{125} \mathrm{I}-\mathrm{NGF}$ binding studies was calculated from optical densities corresponding to specific and nonspecific binding measured on the autoradiograms. Optical densities measured on the autoradiograms were first converted to $\mathrm{nCi} / \mathrm{mg}$ tissue equivalent with the standard curve generated by the calibrated iodinated microscales, then to $\mathrm{fmol} / \mathrm{mg}$ tissue equivalent. Specific binding in each region was determined by substracting the nonspecific binding from total binding.

Statistical analysis. The mean specific ${ }^{125}$ I-NGF binding and the mean intensity of AChE staining were calculated from triplicate sections in each experiment. The average for each region in each patient was then 
calculated from two experiments. The means for the groups of control subjects and AD patients were compared with Student's two-tailed $t$ test.

\section{Results}

Immunohistochemical detection of NGF receptors. In control brain, NGF receptors were detected with antibody ME20-4 in cell bodies and proximal neurites in the nucleus of the diagonal band of Broca and the nucleus basalis of Meynert (Fig. 1A-C). Within cell bodies, the reaction product was concentrated at the neuronal membrane and in the perinuclear area. No immunostaining was observed in the striatum.

In brains from $\mathrm{AD}$ patients, immunoreactivity was globally decreased in the nucleus basalis of Meynert. Some of the surviving immunostained neurons displayed shorter and less numerous processes than in control brain (Fig. 1B-D).

Characterization of ${ }^{125}$ I-NGF binding in brains from control subjects and $A D$ patients. ${ }^{125} \mathrm{I}-\mathrm{NGF}$ binding was saturable with a $K_{d}$ of $3.5-4 \times 10^{11} \mathrm{M}$ and a $B_{\max }$ of $0.31 \mathrm{fmol} / \mathrm{mg}$ tissue equivalent in the striatum, and a $K_{d}$ of $2.5-3 \times 10^{-11} \mathrm{M}$ and a $B_{\max }$ of $0.23 \mathrm{fmol} / \mathrm{mg}$ tissue equivalent in the substantia innominata of a control subject. In the AD patient, the $K_{d}(3-3.5 \times$ $10^{-11} \mathrm{M}$ ) was similar to the control value in the dorsal striatum. $K_{d}$ and $B_{\max }$ values could not be determined for the ventral striatum, where receptor density was too low (see below).

${ }^{125} \mathrm{I}-\mathrm{NGF}\left(4 \times 10^{-11} \mathrm{M}\right)$ was displaced by the unlabeled ligand (Fig. 2). The $K_{i}$ calculated from the curve was $9 \times 10^{-9} \mathrm{M}$. Nonspecific binding, defined with $4 \times 10^{-8} \mathrm{M}$ unlabeled NGF, represented $50 \%$ of the total binding.

$A C h E$ activity in the striatum homogenates. In order to ascertain that $\mathrm{AChE}$ optical density values correlated with $\mathrm{AChE}$ activity in tissue sections, AChE activity was determined in different dilutions of striatal homogenates. Using Pearson's linear regression, a linear relationship was observed between striatal tissue dilution and AChE optical density values $(p<0.01$ for $1.5 \mathrm{hr} \mathrm{AChE}$ reaction time). In addition, a significant correlation was also observed between the different times of incubation in $\mathrm{AChE}$ reaction solution and $\mathrm{AChE}$ optical density values for the three highest concentrations of AChE standards (including that corresponding to pure striatal gray matter) $(10 /$

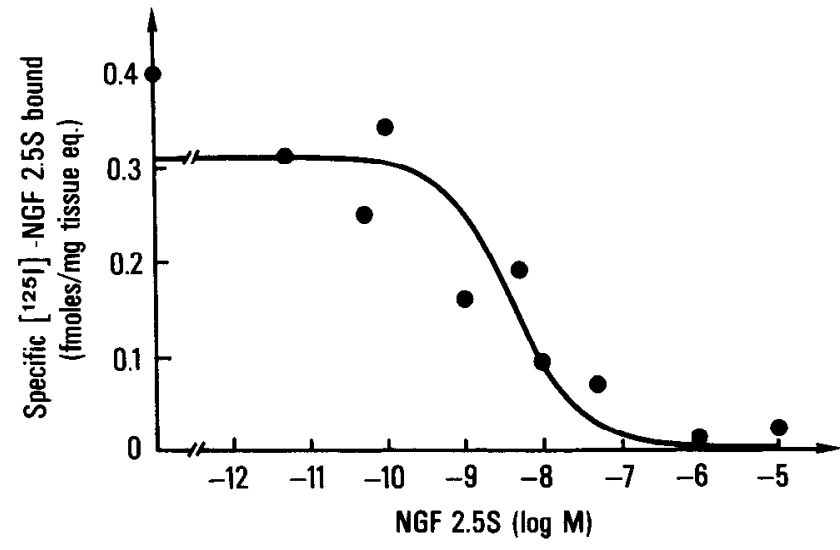

Figure 2. Characterization of ${ }^{125}$ I-NGF $2.5 \mathrm{~S}$ binding in the human striatum. Displacement of ${ }^{12} \mathrm{I}$ I-NGF $2.5 \mathrm{~S}\left(4 \times 10^{-11} \mathrm{M}\right)$ from slidemounted sections of human striatum with eight concentrations of NGF 2.5S ranging from $5 \times 10^{-11}$ to $1 \times 10^{-5} \mathrm{M}$. Data are from a single representative experiment performed with triplicate sections.

10 gray matter: $p<0.004, r=0.98 ; 9 / 10: p<0.01, r=0.97$; 8/10: $p=0.004, r=0.98)$.

${ }^{125}$ I-NGF binding and AChE activity in control subjects. Autoradiograms of ${ }^{125} \mathrm{I}-\mathrm{NGF}$ binding in the striatum and mesencephalon of a control subject are shown in Figure 3. Binding levels were high in the caudate nucleus, putamen, and ventral striatum and in the nucleus basalis of Meynert, low in the globus pallidus, and undetectable in the nucleus tegmenti pedunculopontinus. The mean specific binding levels of ${ }^{125} \mathrm{I}-\mathrm{NGF}$ in the striatum and nucleus basalis of Meynert of the control subjects are given in Table 2 . There were no significant differences in binding among the regions studied. The rostrocaudal distribution of ${ }^{125} \mathrm{I}-\mathrm{NGF}$ binding sites in the striatum, pallidum, and nucleus basalis of Meynert, determined in one control brain, was also homogeneous (not shown).

Local variations in binding were evident in the striatum, where patches of low density were surrounded by a more heavily labeled matrix (Fig. $4 A$ ). These areas of low binding could be superimposed on $\mathrm{AChE}$-poor regions on adjacent sections. High

Table 2. Specific ${ }^{125 I-N G F ~ 2.5 S}$ binding (fmol/mg of tissue equivalent) and AChE staining in control subjects and patients with Alzheimer's disease

\begin{tabular}{|c|c|c|c|c|}
\hline \multirow[b]{2}{*}{ Structure } & \multicolumn{2}{|l|}{ Control } & \multicolumn{2}{|l|}{ Alzheimer } \\
\hline & $\begin{array}{l}\text { NGF binding } \\
\text { (fmol/mg tissue } \\
\text { equivalent) }\end{array}$ & $\begin{array}{l}\text { AChE } \\
\text { OD } \times 100\end{array}$ & $\begin{array}{l}\text { NGF binding } \\
\text { (fmol/mg tissue } \\
\text { equivalent) }\end{array}$ & $\begin{array}{l}\text { AChE } \\
\text { OD } \times 100\end{array}$ \\
\hline Caudate nucleus & $0.35 \pm 0.04$ & $5.2 \pm 0.2$ & $0.10 \pm 0.05(-69 \%)^{*}$ & $4.9 \pm 0.1(-4 \%)$ \\
\hline Upper & $0.32 \pm 0.06$ & $5.4 \pm 0.2$ & $0.11 \pm 0.05(-65 \%)^{*}$ & $5.3 \pm 0.3(-2 \%)$ \\
\hline Lower & $0.37 \pm 0.04$ & $5.0 \pm 0.2$ & $0.07 \pm 0.06(-82 \%)^{*}$ & $4.8 \pm 0.4(-3 \%)$ \\
\hline Putamen & $0.32 \perp 0.09$ & $5.5 \pm 0.3$ & $0.03 \pm 0.02(-90 \%)^{*}$ & $4.8 \pm 0.3(-12 \%)$ \\
\hline Upper & $0.33 \pm 0.10$ & $5.6 \pm 0.3$ & $0.01 \pm 0.01(-96 \%)^{*}$ & $5.1 \pm 0.3(-7 \%)$ \\
\hline Lower & $0.28 \pm 0.12$ & $5.3 \pm 0.3$ & ND & $4.3 \pm 0.5(-18 \%)$ \\
\hline Ventral striatum & $0.49 \pm 0.15$ & $5.6 \pm 0.3$ & $0.04 \pm 0.02(-92 \%)^{*}$ & $4.4 \pm 0.9(-24 \%)$ \\
\hline Nucleus basalis of Meynert & $0.44 \pm 0.08$ & $6.4 \pm 0.4$ & $0.04 \pm 0.03(-91 \%)^{*}$ & $4.2 \pm 0.1(-34 \%)^{*}$ \\
\hline $\begin{array}{l}\text { Nucleus tegmenti } \\
\text { pedunculopontinus }\end{array}$ & ND & 4.9 & ND & $4.7(-4 \%)$ \\
\hline
\end{tabular}

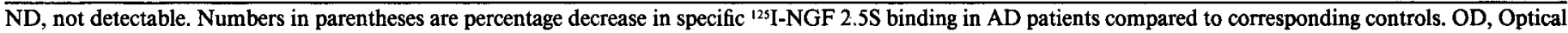
density. Data are the mean $\pm \mathrm{SD}$.

$* p<0.02$. 


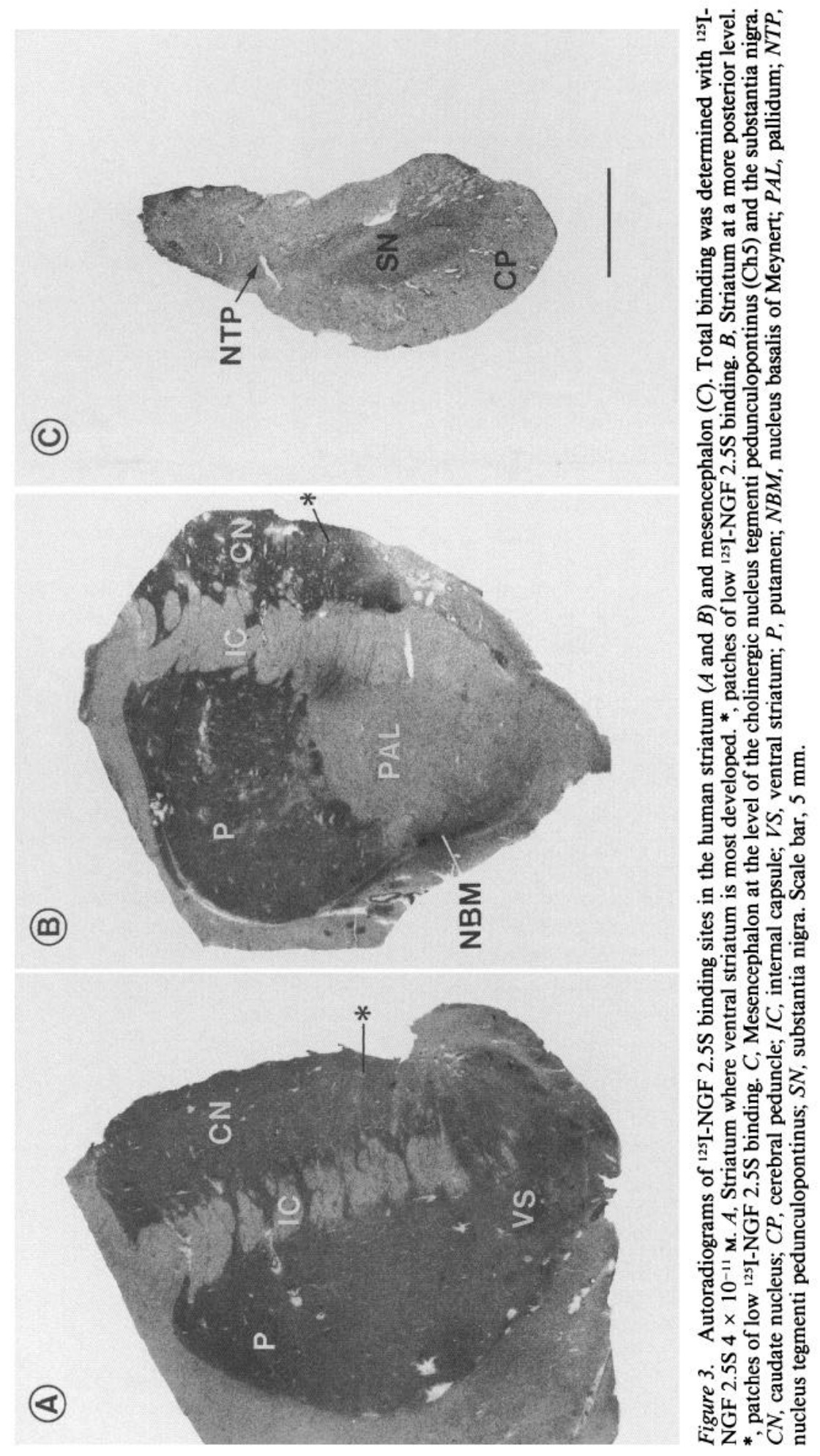



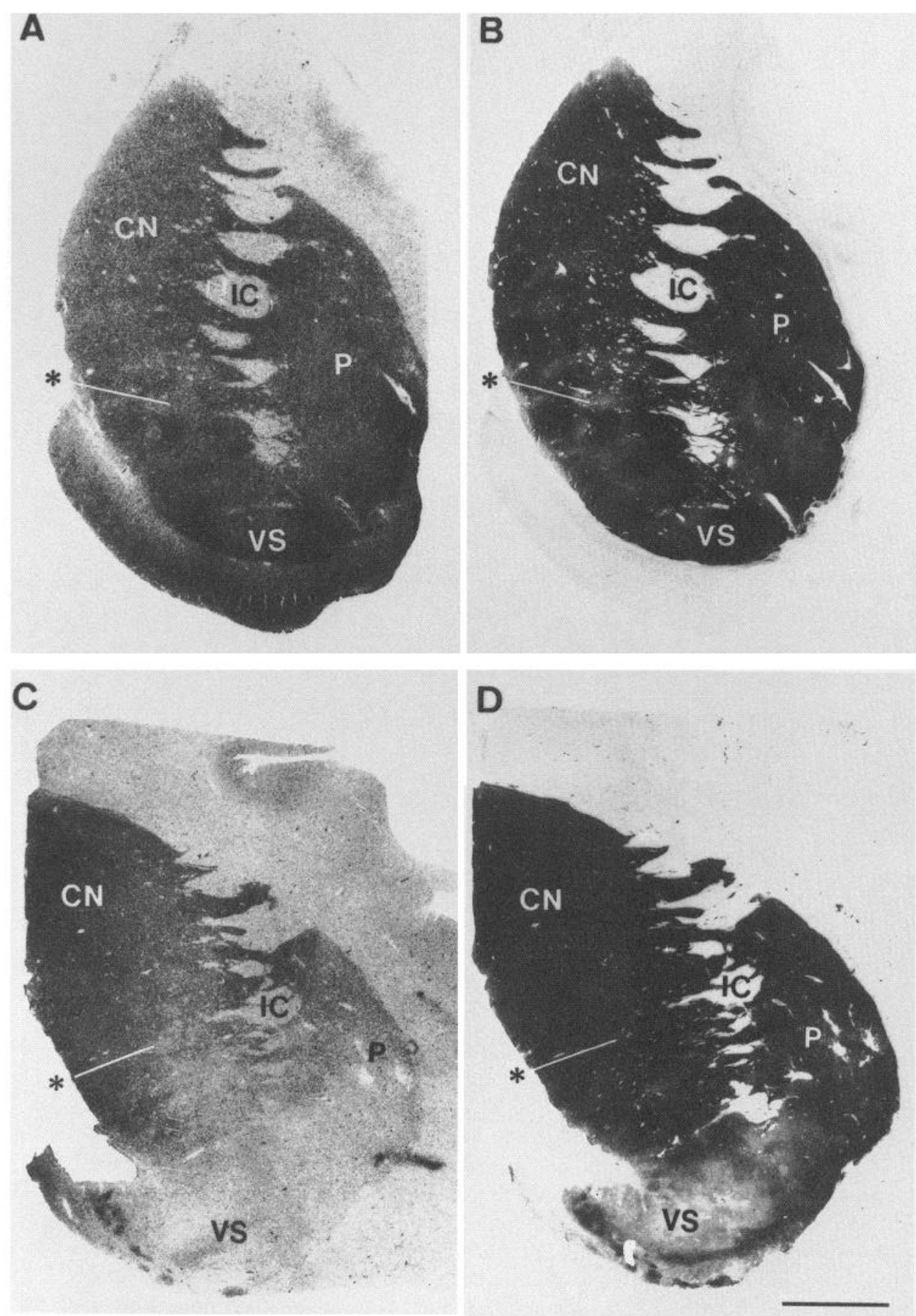

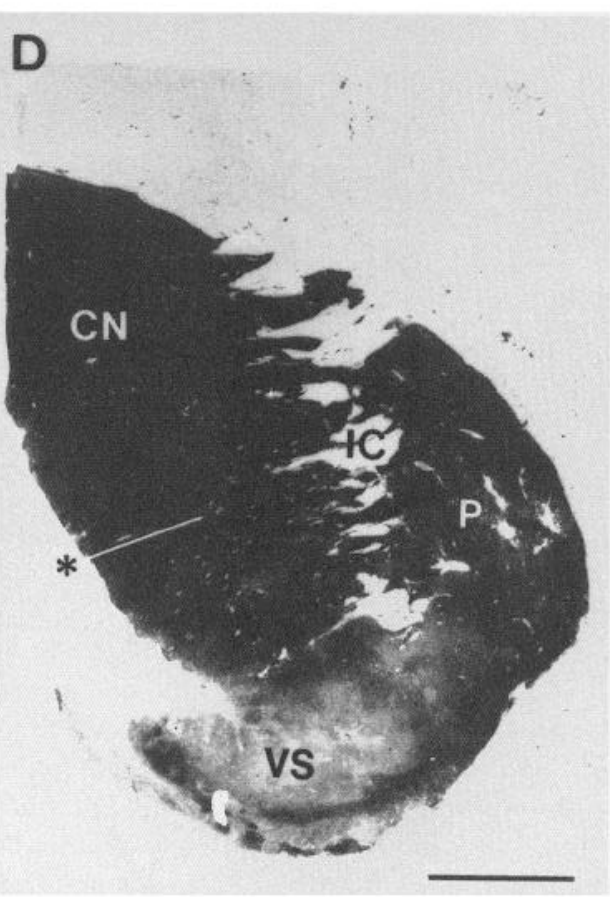

Figure 4. Autoradiogram of ${ }^{125} \mathrm{I}-\mathrm{NGF}$ $2.5 \mathrm{~S}$ binding sites $(A-C)$ and AChE histochemistry $(B-D)$ on adjacent frontal sections of the human striatum of a control subject $(A, B)$ and a patient with Alzheimer's disease $(C, D)$. *, AChEpoor striosomes and low ${ }^{125}$ I-NGF $2.5 \mathrm{~S}$ binding. $C N$, caudate nucleus; $I C$, internal capsule; $V S$, ventral striatum; $P$, putamen. Scale bar, $5 \mathrm{~mm}$. receptor densities corresponded to the AChE-rich matrix (Fig. $4 A, B)$. The striosome: matrix ratios calculated for ${ }^{125} \mathrm{I}-\mathrm{NGF}$ binding (caudate nucleus, 0.40 ; putamen, 0.36 ; and ventral striatum, 0.35) were similar to the ratio of AChE activity (caudate nucleus, 0.29; putamen, 0.35; ventral striatum, 0.36).

${ }^{125} \mathrm{I}-\mathrm{NGF}$ binding and AChE activity in patients with Alzheimer's disease. Specific ${ }^{125} \mathrm{I}-\mathrm{NGF}$ binding and AChE activity were decreased in the nucleus basalis of Meynert and striatum of AD patients compared to controls (Fig. 4C,D; Table 2). The loss was most severe in the ventral striatum and in the putamen. The lower halves of the caudate nucleus and the putamen were slightly more affected than the upper halves (Table 2). In the nucleus basalis of Meynert, the density of NGF receptors was reduced to the same extent as the most affected striatal region. No binding was observed in the nucleus tegmenti pedunculopontinus. The striosomal organization of NGF receptors was still visible in the caudate nucleus and putamen, but not in the ventral striatum (Fig. 4C).

As shown in Figure 5 (top), NGF receptor density varied among patients. Those with the most severe symptoms (no. 10 and 11) had no detectable NGF binding in the striatum, although some binding could be detected in recently diagnosed patients (no. 6 and 7).

The intensity of AChE staining decreased significantly in the 
Figure 5. Specific binding of ${ }^{125}$ I-NGF $2.5 \mathrm{~S}\left(4 \times 10^{-11} \mathrm{M}\right.$; top $)$ and AChE staining (bottom) in the striatum and substantia innominata of control subjects (no. 1-5) and Alzheimer patients (no. experiments with triplicate sections. Nonspecific binding was determined in the presence of $4 \times 10^{8} \mathrm{M}$ of NGF $2.5 \mathrm{~S}$. OD, Optical density $\times 100$. 6-11). Data represent the mean of two
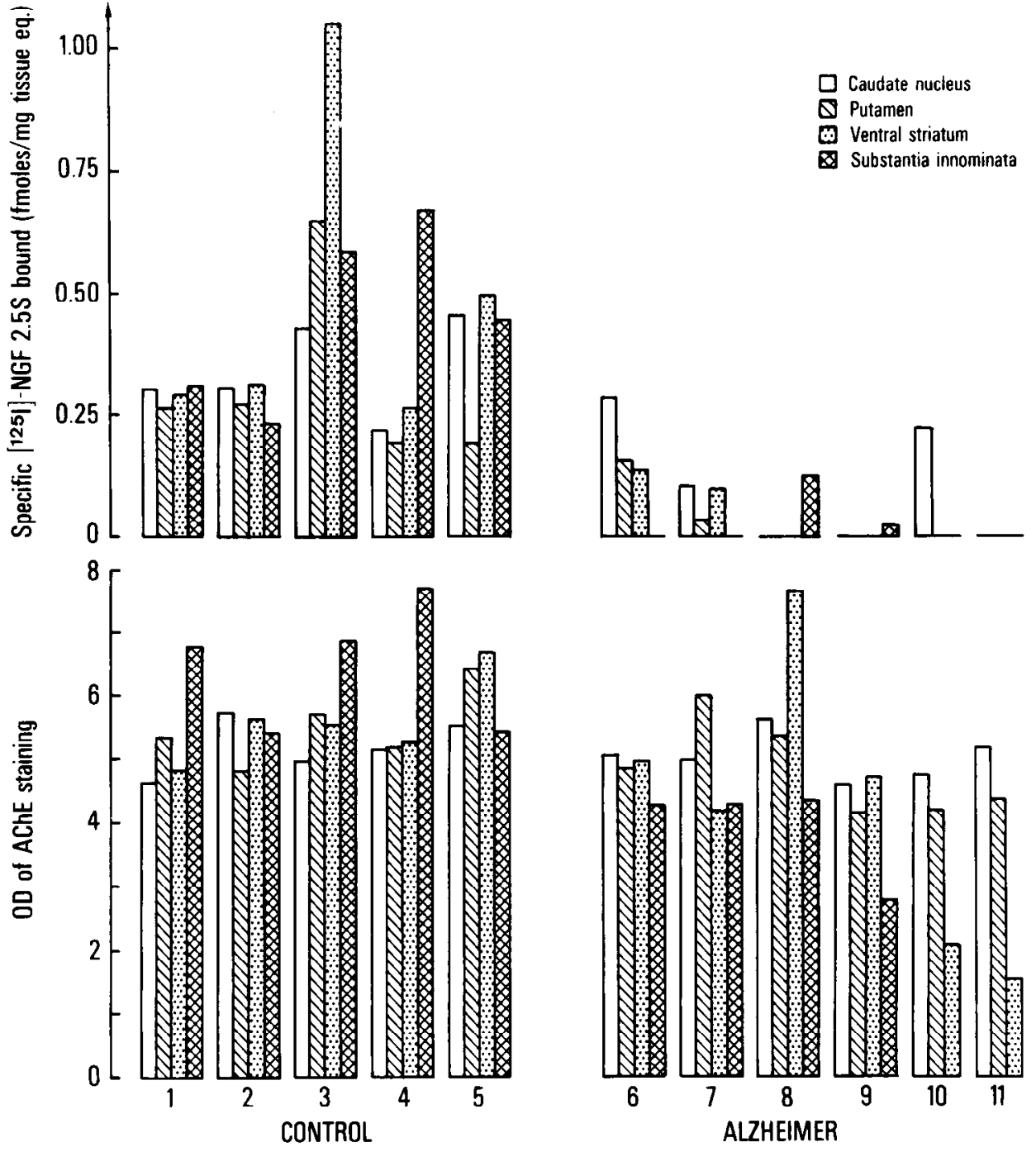

nucleus basalis of Meynert (Table 2). The mean decrease was $34 \%$ compared to controls, but varied among patients, being less pronounced in those who were less affected (Fig. 5, bottom). In the ventral striatum, AChE staining in the neuropil was severely decreased in the most affected patients (no. 10 and 11), and moderately in the others, except in one patient (no. 8), where no change was observed. AChE staining in the dorsal caudate nucleus and putamen and in the nucleus tegmenti pedunculopontinus was similar to that of controls (Table 2).

\section{Discussion}

Under our experimental conditions, ${ }^{125}$ I-NGF bound specifically to a population of NGF binding sites in human brain. The $K_{d}$ and $B_{\max }$, determined by saturation analysis, were comparable to those reported for high-affinity NGF receptors in the same regions of rat brain (Richardson et al., 1986). Competition with a 1000-fold excess of unlabeled NGF failed, however, to abolish binding completely: this residual binding may represent nonspecific sites. Another possibility is that NGF also bound, in our experiments, to the receptor of a related growth factor, such as brain-derived neurotrophic factor, with which it shares $50 \%$ sequence homology (Leibrock et al., 1989). At high concentrations, cross-recognition of the receptors is assumed to be pos- sible (Davies, 1988; Rodriguez-Tébar et al., 1990), but this seems unlikely with the picomolar concentration of NGF used in this study.

In normal human brains, we were able to evidence, by both immunohistochemical and autoradiographic techniques, the presence of NGF binding sites in the nucleus basalis of Meynert and their absence in the mesencephalic nucleus pedunculopontinus, in accordance with previous immunohistochemical and autoradiographic studies in human (Hefti and Mash, 1989) and rat brain (Richardson et al., 1986). In the striatum, however, the results obtained with the two techniques were discordant. No receptors were detected by immunohistochemistry, as in a previous study in human (Hefti and Mash, 1989; Mufson et al., 1989 a), although they were clearly present with autoradiographic analysis, confirming in human brain a previous observation in the rat (Richardson et al., 1986). The discrepancy between the immunohistochemical and autoradiographic observations in the striatum might be attributable to the greater sensitivity of the latter technique (Raisman-Vozari et al., 1991). This explanation is not entirely satisfactory, however, since receptor densities in the striatum, according to our autoradiographic results, were quite similar to those in the nucleus basalis of Meynert. A second possibility is that the striatal receptors represent a subpopulation 
that is not recognized by the monoclonal antibody used in the study, reported to label a low-affinity NGF receptor on human melanoma cclls of neural crest origin (Ross et al., 1984). A recent study has demonstrated that the $140 \mathrm{kDa}$ trk proto-oncogene protein is necessary for high-affinity NGF binding (Heampstead et al., 1991). An unidentified high-affinity NGF binding protein of similar molecular weight, antigenically distinct from the lowaffinity receptor, has also been described (Weskamp and Reichardt, 1991). If these proteins, in the absence of the low-affinity sites, are responsible for the high-affinity NGF binding in the striatum, this would explain the discrepancy between the immunocytological and autoradiographic data. The relationship between this receptor and low-affinity NGF receptor in the brain is not, however, clearly determined.

The present immunohistochemical and autoradiographic studies in human brain provide evidence that the density of NGF receptors is decreased in the nucleus basalis of Meynert in patients with $\mathrm{AD}$. This is in agreement with previous studies (Hefti and Mash, 1989; Kordowcr ct al., 1989; Mufson et al., 1989b; Allen et al., 1990). The autoradiographic data indicate, in addition, that NGF receptors present in the striatum decrease in density as well. This decrease was not due to a change in affinity of the receptor, since $K_{d}$ values in control and AD samples were similar, nor was it due to factors such as age, postmortem delay, premortem conditions, or therapy, since no correlations could be found between these factors and the receptor binding data. The question is then whether this decrease in density represents loss of receptors from the cells that normally bear them, loss of the cells, or both.

The dominant hypothesis is that the receptors are located on cholinergic neurons known to degenerate in AD. Although not all cholinergic neurons have NGF receptors, as illustrated by the nucleus pedunculopontinus in this and other studies (Hefti and Mash, 1989; Mufson et al., 1989a), in the nucleus basalis of Meynert, colocalization of NGF receptors and ChAT (a specific marker of cholinergic neurons), detected immunocytochemically, has been reported in both animals (Kordower et al., 1988; Pioro and Cuello, 1990) and humans (Kordower et al., 1989; Mufson et al., 1989). The effects of NGF on cholinergic neurons in the nucleus basalis of Meynert are well known: it promotes growth of the neurons and prevents their atrophy and death in adult brain (Fischer et al., 1987). In the rat striatum where NGF is indeed present (Whittemore and Seiger, 1987), the localization of the NGF receptors remains to be determined, and it may include noncholinergic neurons and glial cells as well (Dreyfus et al., 1989; Gage et al., 1989; Pioro and Cuello, 1990).

In order to address this question, we studied the distribution of receptor binding and AChE staining, a good index of AChE activity (Wenk and Krug, 1975; Kugler, 1988), on adjacent sections. In normal brain, receptor density followed the pattern of cholinergic innervation. This was particularly clear in the striatum where striosome/matrix distributions were identical. AChE staining decreased in the nucleus basalis of Meynert of AD patients, in parallel with the decrease in NGF binding density, but to a much lesser degree. In the striatum the difference was even greater: $\mathrm{AChE}$ activity decreased detectably only in the ventral striatum, and only in the most affected patients, whereas NGF receptor density decreased quite massivcly in all regions of the striatum. Given that (1) AChE activity was measured in the initial rate phase of $A C h E$ reaction, as evidenced by the linear relation between time of reaction and $\mathrm{AChE}$ optical density, and (2) AChE optical density was proportional to AChE dilution, as shown by the linear relationship between striatal standards dilutions and AChE optical density, the decrease in AChE optical density in AD patients may reflect a true quantitative loss of AChE activity. It is thus tempting to speculate that loss of the receptors precedes, and might even cause, cell degeneration in AD.

Before this hypothesis can be seriously considered, however, other explanations, including possible methodological artifacts, must be excluded. First of all, AChE is found in some noncholinergic as well as in cholinergic neurons. Loss of the latter may, then, be underestimated with this marker. AChE was chosen as a marker in this study, in preference to the more spccific immunohistochemical detection of ChAT, because it could be performed on the same tissue preparation as receptor binding, but a colocalization study with the more specific marker remains indispensable. A $>50 \%$ loss of ChAT-immunoreactive neurons has been reported in the nucleus basalis of Meynert in $A D$ patients (Nagai et al., 1983; Mufson et al., 1989b), and a 60\% loss in the ventral striatum (Lehéricy et al., 1989), which is still far from the $90 \%$ decrease in NGF receptors. A second possibility is that some NGF receptors are located on noncholinergic neurons that degenerate, particularly in the striatum, but such neurons have not yet been identified. Finally, the possibility that surviving cholinergic neurons in AD patients have fewer NGF receptors is not supported by in situ hybridization experiments, which show normal or increased expression of NGF receptor mRNA in the nucleus basalis of Meynert in AD patients (Goedert et al., 1989; Ernfors et al., 1990), although protein expression and mRNA transcription are not necessarily regulated in parallel.

Can loss of NGF receptors play a role in the death of cholinergic neurons in AD? The observation that cholinergic neurons that normally have NGF receptors degenerate in AD whereas those that do not are spared suggests that there might be a relationship between the two phenomena. The loss of the receptors may be a primary factor in the pathogenesis of the disease or a precocious sign of suffering in cells that are dying for other reasons. However, morphologically abnormal, presumably dying neurons were observed in the nucleus basalis of Meynert in this study that were immunoreactive for NGF receptors, suggesting that the protein was still expressed in these cells. It needs to be determined whether these receptors are functional and whether they are appropriately stimulated by their normal ligand. It is known that NGF plays a role in the development of cholinergic systems in the striatum (Martinez et al., 1985; Mobley et al., 1985; Johnston et al., 1987; Mobley et al., 1989); its role in the maintenance of these systems in the adult and the pathogenesis of AD still need to be elucidated.

\section{References}

Allen SJ, Dawbarn D, MacGowan SH, Wilcock GK, Treanor JJS, Moss TH (1990) Quantitative morphometric analysis of basal forebrain neurons expressing $\beta$-nerve growth factor receptors in normal and Alzheimer's disease brains. Dementia 1:125-137.

Bodian D (1936) A new method for staining nerve fibers and nerve endings in mounted paraffin sections. Anat Rec 65:89-98.

Brandel JP, Hirsch EC, Malessa S, Duyckaerts C, Cervera P, Agid Y (1991) Differential vulncrability of cholinergic projections to the mediodorsal nucleus of the thalamus in senile dementia of Alzheimer type and progressive supranuclear palsy. Neuroscience 41:25-31.

Davies AM (1988) The emerging generality of the neurotrophic hypothesis. Trends Neurosci 11:243-244.

Dreyfus CH, Bernd P, Martinez H, Rubin ST, Black IB (1989) GA- 
BAergic and cholinergic neurons exhibit high-affinity nerve growth factor binding in rat basal forebrain. Exp Neurol 104:181-185.

Ernfors P, Linderfors N, Chan-Palay V, Persson H (1990) Cholinergic neurons of the nucleus basalis express elevated levels of nerve growth factor receptor mRNA in senile dementia of the Alzheimer type. Dementia 1:138-145.

Fischer W, Wicktorin K, Bjorklund A, Williams LR, Varon S, Gage FH (1987) Amelioration of cholinergic neuron atrophy and spatial memory impairment in aged rats by nerve growth factor. Nature 329: $65-68$.

Gage FH, Batchelor P, Chen KS, Chinn D, Higgins GA, Koh S, Deputy S, Rosenberg MB, Fischer W, Bjorklund A (1989) NGF receptor reexpression and NGF mediated cholinergic neuronal hypertrophy in the damaged adult neostriatum. Neuron 2:1177-1184.

Goedert M, Fine A, Dawbarn D, Wilcock GK, Chao MV (1989) Nerve growth factor receptor mRNA distribution in human brain: normal levels in basal forebrain in Alzheimer's disease. Mol Brain Res 5:1-7.

Graybiel AM, Ragsdale CW (1978) Histochemically distinct compartments in the striatum of human, monkey and cat demonstrated by acetylthiocholinesterase staining. Proc Natl Acad Sci USA 75: $5723-5726$.

Graybiel AM, Hirsch EC, Agid YA (1987) Differences in tyrosine hydroxylase-like immunoreactivity characterize the mesostriatal innervation of striosomes and extrastriosomal matrix at maturity. Proc Natl Acad Sci USA 84:303-307.

Hefti F, Mash DC (1989) Localization of nerve growth factor receptors in the normal human brain and in Alzheimer's disease. Neurobiol Aging 10:75-87.

Hempstead BL, Martin-Zanca D, Kaplan DR, Parada BLF, Chao MV (1991) High-affinity NGF binding requires coexpression of the trk proto-oncogene and the low-affinity NGF receptor. Nature 350:678683.

Hirsch EC, Graybiel AM, Hersh LB, Duyckaerts C, Agid Y (1989) Striosomes and extrastriosomal matrix contain different amounts of immunoreactive choline acetyltransferase in the human striatum. Neurosci Lett 96:145-150.

Johnston MV, Rutkowski JL, Wainer BH, Long JB, Mobley WC. (1987) NGF effects on developing forebrain cholinergic neurons are regionally specific. Neurochem Res 12:985-994.

Kordower JH, Bartus RT, Bothwell M, Schatteman G, Gash DM (1988) Nerve growth factor receptor immunoreactivity in the nonhuman primate (Cebus apella): distribution, morphology, and colocalization with cholinergic enzymes. J Comp Neurol 277:465-486.

Kordower JH, Gash DM, Bothwell M, Hersh L, Mufson E (1989) Nerve growth factor and choline acetyltransferase remain colocalized in the nucleus basalis (Ch4) of Alzheimer's patients. Neurobiol Aging 10:67-74

Kugler P (1988) Quantitative enzyme histochemistry in the brain. Histochemistry 90:99-107.

Lamy C, Duyckaerts C, Delaere P, Payan C, Fermanian J, Poulain V, Hauw JJ (1989) Comparison of seven staining methods for senile plaques and neurofibrillary tangles in a prospective series of 15 elderly patients. Neuropathol Appl Neurobiol 15:563-578.

Lchćricy S, Hirsch EC, Cervera P, Hersh LB, Hauw JJ, Ruberg M, Agid $Y$ (1989) Selective loss of cholinergic neurons in the ventral striatum of patients with Alzheimer disease. Proc Natl Acad Sci USA 86:85808584.

Leibrock J, Lottspeich F, Hohn A, Hofer M, Hengerer B, Masiakowski P, Thoenen H, Barde YA (1989) Cloning and expression of brainderived neurotrophic factor. Nature 341:149-152.

Levi-Montalcini R, Angeletti PU (1968) Nerve growth factor. Physiol Rev 8:534-569.

Martinez HJ, Dreyfus CF, Jonakait DG, Black IB (1985) Nerve growth factor promotes cholinergic development in brain striatal cultures. Proc Natl Acad Sci USA 82:7777-7781.

McKhann G (1984) Clinical diagnosis of Alzheimer's disease: report of the NINCDS-ADRDA Work Group under the auspices of Department of Health and Human Services Task Force on Nlzheimer's disease. Neurology 34:939-944.

Mesulam MM, Mufson EJ, Wainer BH, Levey AI (1983) Central cholinergic pathways in the rat: an overview based on an alternative nomenclature (Ch1-Ch6). Neuroscience 10:1185-1201.

Mobley WC, Rutkowski JL, Tennekoon GI, Buchanan K, Johntson MV (1985) Choline acetyltransferase activity in striatum of neonatal rats increased by nerve growth factor. Science 229:284-287.

Mobley WC, Woo JE, Edwards RH, Riopelle RJ, Longo FM, Weskamp G, Otten U, Valletta JS, Johntson MV (1989) Developmental regulation of nerve growth factor and its receptor in the rat caudateputamen. Neuron 3:655-664.

Mufson EJ, Bothwell M, Hersh LB, Kordower HJ (1989a) Nerve growth factor receptor immunoreactive profiles in the normal, aged human basal forebrain: colocalization with cholinergic neurons. J Comp Neurol 285:196-217.

Mufson EJ, Bothwell M, Kordower JH (1989b) Loss of nerve growth factor receptor-containing neurons in Alzheimer's disease: a quantitative analysis across subregions of the basal forebrain. Exp Neurol 105:221-232.

Nagai T, McGeer PL, Peng JH, McGeer EG, Dolman CE (1983) Choline acetyltransferase immunohistochemistry in brains of Alzheimer's disease patients and controls. Neurosci Lett 36:195.

Pioro EP, Cuello AC (1990) Distribution of nerve growth factor receptor-like immunoreactivity in the adult rat central nervous system. Effect of colchicine and correlation with the cholinergic system. I. Forebrain. Neuroscience 34:57-87.

Raisman-Vozari R, Hirsch E, Javoy-Agid F, Vassort C, Savasta M, Feurestein C, Thibault J, Agid Y (1991) Quantitative autoradiography of tyrosine hydroxylase immunoreactivity in the rat brain. $J$ Neurochem 57:1212-1222.

Raivich G, Kreutzberg GW (1987) The localization and distribution of high affinity $\beta$-nerve growth factor binding sites in the central nervous system of the adult rat. A light microscopic autoradiographic study using ${ }^{125}$ I $\beta$-nerve growth factor. Neuroscience 20:23-36.

Ransmayr G, Cervera P, Hirsch E, Ruberg M, Hersh LB, Duyckaerts C, Hauw J-J, Delumeau C, Agid Y (1989) Choline acetyltransferaselike immunoreactivity in the hippocampal formation of control subjects and patients with Alzheimer's disease. Neuroscience 32:701714.

Richardson PM, Verge Issa VMK, Riopelle RJ (1986) Distribution of neuronal receptors for nerve growth factor in the rat. $\mathbf{J}$ Neurosci 6:2312-2321.

Rodriguez-Tébar A, Dechant G, Barde YA (1990) Binding of brainderived neurotrophic factor to the nerve growth factor receptor. Neuron 4:487-492.

Ross AH, Grob P, Bothwell M, Elder DE, Ernst CS, Marano N, Ghrist BFD, Slemp CC, Herlyn M, Atkinson B, Koprowski H (1984) Characterization of nerve growth factor receptor in neural crest tumors using monoclonal antibodies. Proc Natl Acad Sci USA 81:6681-6685.

Rossor MN, Garret NJ, Johonson AL, Mountjoy CQ, Roth M, Iversen LL (1982) A postmortem study of the cholinergic and GABA systems in senile dementia. Brain 105:313-330.

Sternberger LA (1979) Immunocytochemistry. New York: Wiley.

Thoenen H, Bandtlow C, Heumann R (1987) The physiological function of nerve growth factor in the central nervous system: comparison with the periphery. Rev Physiol Biochem Pharmacol 109:145-178.

Wenk H, Krug H (1975) Zur histophotometrischen Quantifizierung von Enzymreaktionen dargestellt am Biespiel von Acetylcholinesterase. Acta Histochem [Suppl] 15:433-440.

Weskamp G, Reichardt LF (1991) Evidence that biological activity of NGF is mediated through a novel subclass of high affinity receptors. Neuron 6:649-663.

Whittemore SR, Seiger A (1987) The expression, localization, and functional significance of $\beta$-nerve growth factor in the central nervous system. Brain Res Rev 12:439-464.

Woolf NJ, Jacobs RW, Butcher LL (1989a) The pontomesencephalotegmental cholinergic system does not degenerate in Alzheimer's disease. Neurosci Lett 96:277-282.

Woolf NJ, Gould E, Butcher LL (1989b) Nerve growth factor receptor is associated with cholinergic neurons of the basal forebrain but not the pontomesencephalon. Neuroscience 30:143-152. 